University of St. Thomas, Minnesota

UST Research Online

2009

\title{
A Comparison of the New U.S. Expatriation Tax and the Canadian Departure Tax
}

Alexander M. Gelardi

University of St. Thomas, Minnesota, amgelard@stthomas.edu

Follow this and additional works at: https://ir.stthomas.edu/ocbacctpub

Part of the Accounting Commons

This Article is brought to you for free and open access by the Accounting at UST Research Online. It has been accepted for inclusion in Accounting Faculty Publications by an authorized administrator of UST Research Online. For more information, please contact asle4660@stthomas.edu. 


\title{
A Comparison of the New U.S. Expatriation Tax and the Canadian Departure Tax
}

Alexander M. G. Gelardi

\begin{abstract}
The Heroes Earnings Assistance and Relief Tax Act of 2008 amended the anti-avoidance provisions of the Internal Revenue Code for an expatriating taxpayer. The new law requires expatriating taxpayers to report a deemed taxable sale and repurchase of assets at the time that they expatriate. This is a change from the prior law where an expatriating taxpayer could be taxed by the U.S. for ten years after expatriation. The new U.S. rules are similar to rules that have been used by Canada to tax expatriating Canadian residents. This paper sets out the new U.S. rules and compares them to the Canadian departure tax. As can be seen, there are a number of similarities between the two countries' laws. However, there are also some major differences. The U.S. rules are more limited in application than the Canadian rules. As well as income tax, the U.S. legislators are concerned with estate and gift taxes, whereas the Canadian legislators are not.
\end{abstract}

Keywords: expatriation; tax; Canada; United States.

\section{INTRODUCTION}

On June 17, 2008, President George W. Bush signed the new Heroes Earnings Assistance and Relief Tax Act of 2008 (Heroes Act). ${ }^{1}$ It provides a number of tax provisions to help military families. To help pay for the relief to the military families, however, the Act added further burdens to persons expatriating from the United States. The new law adds a "departure" tax for U.S. citizens giving up their U.S. citizenship and for long-term permanent residents giving up their U.S. residency status. This new provision will have a major impact on U.S. taxpayers who wish to remove themselves from the U.S. tax system. ${ }^{2}$

The U.S. is not unique in addressing this problem of expatriation. However, only one of our major trading partners has also addressed the problem through the income tax system. That country is Canada. The two countries have both similarities and differences in their underlying tax structures. For example, Canada taxes the worldwide income of individuals on a residency basis, whereas the U.S. taxes such income on both a citizenship basis as well as a residency basis. In Canada, all persons who are regarded as being resident for tax purposes are so

Alexander M. G. Gelardi is an Associate Professor at the University of St. Thomas.

The author thanks the two anonymous reviewers, and especially the editor, Ed Schnee, for their suggestions, which improved the paper greatly.

1 PL 110-245. H.R. 6081-110th Congress (2008): Heroes Earnings Assistance and Relief Tax Act of 2008. The Heroes Act $\S 301(\mathrm{a})$ adds $\S 877 \mathrm{~A}$ to the Internal Revenue Code (IRC).

2 This paper discusses the new provisions as they relate to taxpayers who are individuals. 
taxed. For U.S. taxation, all citizens, whether resident in the U.S. or not, are taxed on their worldwide income. Residents of the U.S. for tax purposes include legal permanent residents ("green card" holders, even if living abroad) ${ }^{3}$ and other aliens who have had a substantial presence in the U.S. ${ }^{4}$ A pertinent similarity is that both countries have special rules for taxing capital gains (rather than taxing them as ordinary income). Both the U.S. and Canada base their federal tax laws on common law principles. ${ }^{5}$

The purpose of this paper is to describe the new U.S. law and to compare it with how Canada has tried to address the same problem. Since new laws are rarely made in isolation, it is important to understand how similar problems are addressed by different countries, each working within their particular tax structures. The United States and Canada are not only close neighbors; the two countries are major trading partners and have similar economic values. The tax authorities of the two countries meet regularly to discuss matters of mutual concern and interest. This cross-fertilization of ideas is evident in the new U.S. rules for expatriating taxpayers. This paper contributes to the literature comparing how different countries address similar tax problems.

This paper also has a pedagogical motivation. Globalization has increased awareness among educators of the potential influence one country's policies have over another country's policies. It is important that students are made aware and understand that there are different approaches to addressing similar problems. An aim of this paper is to present educators with an up-to-date example of how two countries which are neighbors address a common problem.

This paper compares the new U.S. rules and the Canadian rules relating to expatriation. The next section sets out the bases of taxation for each country and the rules describing the act of expatriation. This is followed by the income tax provisions in both countries for expatriates, detailing the rules for deemed disposition of assets, the definition of an expatriate in each country, excluded property, and the election to defer the payment of tax. The rules relating to gifts and bequests from an expatriate to a U.S. person follows, and the paper ends with a summary and conclusion section.

\section{BASIS OF TAXATION AND EXPATRIATION}

\section{$\overline{\text { United States }}$}

The U.S. is unique among developed countries in that it taxes its citizens on a worldwide basis wherever they are resident. Most other developed countries tax persons on a worldwide basis only if they are resident and/or domiciled in the particular country. The U.S. also uses a residency basis to tax noncitizens on their worldwide income. Nonresident aliens are taxed on U.S. source income, either directly or through a withholding tax system, subject to any double tax agreements.

In order to avoid being taxed, U.S. citizens who live outside of the U.S. have an incentive to give up their citizenship and U.S. residents to become nonresident. As an anti-avoidance

\footnotetext{
3 Internal Revenue Code (IRC) $§ 7701(b)(1)(a)(i)$.

4 IRC $\S 7701(b)(3)(A)$. Substantial presence is defined as being in the U.S. for at least 183 days (calculated as all days in the current year plus one-third of the days in the prior year and one-sixth of the days in the pre-prior year). The taxpayer needs to have been in the U.S. at least 31 days in the current year.

5 For provincial legal purposes, the province of Quebec uses the civil law rather than common law.
} 
measure, the law in effect prior to the enactment of the Heroes Act made it difficult for citizens ${ }^{6}$ and long-term residents ${ }^{7}$ to escape from the U.S. income and estate tax systems for ten years after expatriation by taxing most U.S.-sourced income or transfer of U.S.-situs assets. ${ }^{8}$ The new rules replace the former rules with what is tantamount to a departure tax.

Since the new rules can apply to former U.S. citizens, the date of expatriation is important in establishing if the new or old rules apply to a taxpayer. That date is determined by immigration law. ${ }^{9}$

A long-term resident is a taxpayer who is a legal permanent resident for at least eight tax years out of the 15 tax years ending with the tax year of losing his permanent residency status. A legal permanent resident, who is treated as a resident of a foreign country under that country's double-tax treaty with the U.S. and who does not waive the treaty rights pertaining to such a resident for a particular year, is not regarded as a legal permanent resident for that particular year when calculating whether he is a long-term resident. ${ }^{10}$ If such a taxpayer did waive his treaty rights in any year, then that year would count as a year of legal permanent residence. A longterm resident expatriates when he is no longer regarded as being a resident of the U.S. This is usually the date he abandons his green card voluntarily or is administratively determined to have abandoned his green card. ${ }^{11}$

\section{$\overline{\text { Canada }}$}

Canada is similar to many developed countries in that it taxes its citizens and residents on a residency basis. Only persons who are resident in Canada for tax purposes are taxed on their worldwide income. Since expatriation for tax purposes is relatively easy, Canadian law imposes a departure tax on taxpayers who stop being Canadian residents. ${ }^{12}$ Canada taxes nonresidents

6 IRC $\S 877(a)$. This paper only deals with the U.S. federal law, and not any state law.

7 IRC $\S 877(\mathrm{e})$.

8 IRC $\S 877(b),(d)$.

$9 \S 349(\mathrm{a})(5)$ of the Immigration and Nationality Act (INA) 8 U.S.C. $\$ 1481(\mathrm{a})(5)$ and IRC $\S 877 \mathrm{~A}(\mathrm{~g})(4)$. The date of expatriation for a former U.S. citizen is the earliest of:

(1) the date the taxpayer renounces his U.S. nationality in front of a U.S. diplomatic or consular official pursuant to the Immigration and Nationality Act;

(2) the date the taxpayer furnishes to the U.S. Department of State a signed statement voluntarily relinquishing his U.S. nationality by performing certain acts, [such as obtaining naturalization in a foreign state; taking an oath, affirmation or other formal declaration to a foreign state or its political subdivisions; entering or serving in the armed forces of a foreign state engaged in hostilities against the U.S., or serving as a commissioned or noncommissioned officer in the armed forces of a foreign state; or accepting employment with a foreign government if (a) one has the nationality of that foreign state, or (b) an oath or declaration of allegiance is required in accepting the position (INA §349(a)(1), (2), (3), and (4)]. There is a presumption that a person performing any of these acts does NOT wish to relinquish his U.S. citizenship. Only if one of these acts is performed with the INTENTION of giving up U.S. citizenship, as evidenced by the signed statement, is U.S. citizenship relinquished;

(3) the date the U.S. Department of State issues to the taxpayer a certificate of loss of nationality, or

(4) the date a court in the U.S. cancels a naturalized citizen's certificate of naturalization.

The first two of the dates only apply if a court in the U.S. later confirms the relinquishment.

10 IRC $\$ 877 \mathrm{~A}(\mathrm{~g})(5)$ referring to $\$ 877(\mathrm{e})(2)$.

${ }^{11}$ IRC $\S 877 \mathrm{~A}(\mathrm{~g})(3)(\mathrm{B})$ referring to $\S 7701(\mathrm{~b})(6)$. A legal permanent resident can voluntarily abandon his permanent residency status by relinquishing his "green card" and completing and submitting Form I-407 to the U.S. authorities.

12 Whether a taxpayer is a citizen of Canada or not is irrelevant for taxation purposes. Thus, the relinquishing of Canadian citizenship by a taxpayer has no tax implications. This is a major difference between U.S. and Canadian citizens with respect to taxation. 
on income earned in Canada through employment or a business carried on in Canada, as well as gains on the disposition of certain property sited in Canada.

The Canadian expatriation rules apply to all taxpayers giving up Canadian residency. Whether a taxpayer has given up Canadian residency is a matter of fact. A number of factors are considered to ascertain whether the taxpayer has given up residence. These factors include:

1. whether the taxpayer's spouse and dependents also leave Canada;

2. whether the taxpayer has disposed of a home in Canada and established a permanent home in another country. If the property in Canada has not been disposed of, then renting out the property on a long-term lease at arm's length to a third party would be an indication of expatriation. If, however, the property is left vacant and available to the taxpayer, or rented out to a relative or on a short-term basis, then those are indications that residency has not been given up;

3. whether the taxpayer has sold his personal property and given up social ties in Canada and acquired them in the foreign country. Factors indicating continued Canadian residency would include:

a) clothing, furniture, furnishings, appliances, and utensils left in Canada;

b) vehicles in Canada that are registered in a province or territory of Canada;

c) driver's license from a province or territory of Canada;

d) keeping Canadian bank accounts and investments;

e) having a guaranteed job available on his return to Canada;

f) being eligible for medical coverage from a province or territory of Canada for more than three months after leaving Canada;

g) keeping memberships in Canadian social, recreational, or religious organizations;

h) keeping professional or union memberships in Canada. If the memberships are converted to nonresident memberships, then that would normally be an indication of expatriation. ${ }^{13}$

Thus, any taxpayer who gives up Canadian residency, as evidenced by his behavior, is subject to the deemed disposition rules. In contrast, the U.S. expatriates to whom deemed disposition rules apply are those with substantial income or assets. Furthermore, a U.S. citizen has to actively give up his citizenship, whereas a Canadian citizen does not.

\section{INCOME TAX PROVISIONS FOR EXPATRIATES}

\section{Deemed Disposition}

\section{United States}

The Heroes Act requires the expatriate to report for tax purposes a deemed sale and repurchase of certain assets on the day before expatriation. ${ }^{14}$ This is a departure from the prior law, where there was generally no deemed disposition of assets on expatriation. Under the prior rules, the expatriate was taxed for ten years after expatriating. If the expatriate spent more than 30 days in the U.S. in any tax year during that time, he was taxed on this worldwide income for that year. ${ }^{15}$ If the expatriate was in the U.S. for 30 days or less, he was taxed on his U.S

\footnotetext{
${ }^{13}$ Adapted from Interpretation Bulletin IT-221R3 (Consolidated) Determination of an Individual's Residence Status, and Canada Revenue Agency form NR 73-Determination of Residency Status (Leaving Canada).

${ }^{14}$ Heroes Act $\S 301(\mathrm{a})$ adds $\S 877 \mathrm{~A}(\mathrm{a})$ to the Internal Revenue Code (IRC).

15 IRC $\S 877(\mathrm{~g})(1)$.
} 


\section{TABLE 1}

\section{Summary of Differences between the United States and Canada}

\begin{tabular}{|c|c|c|}
\hline & United States & Canada \\
\hline Applicable Taxpayers & $\begin{array}{l}\text { Giving up citizenship } \\
\text { Giving up long-term residency }\end{array}$ & Giving up residency \\
\hline Asset Limit & $>$ U.S. $\$ 2,000,000$ & $\begin{array}{l}\text { No limit (report list of assets if } \\
>\$ 25,000)\end{array}$ \\
\hline Income Limit & $\begin{array}{l}>\text { U.S. } \$ 139,000^{a} \text { — average for five } \\
\text { years }\end{array}$ & No limit \\
\hline Gains Taxed & $>\$ 600,000^{\mathrm{b}}$ & All gains \\
\hline Excluded Property & Deferred compensation items & $\begin{array}{l}\text { Certain taxable Canadian property } \\
\text { and registered plans }\end{array}$ \\
\hline Election to Defer Payment & Yes & Yes \\
\hline Tax Rate (Federal) & $28 \%$ or $15 \%$ & $14.5 \%{ }^{c}$ \\
\hline \multicolumn{3}{|c|}{$\begin{array}{l}\text { a } \$ 145,000 \text { for } 2009 . \\
\text { b } \$ 626,000 \text { for } 2009 \text {. } \\
\text { c ITA } \$ 38(\text { a). Only half of a taxpayer's capital gains is included in taxable income. Thus, the federal top marginal rate for capital } \\
\text { gains is half of the normal top rate of } 29 \text { percent. }\end{array}$} \\
\hline
\end{tabular}

source income (as expanded). The expanded U.S. source income included gains on the sale of personal property located in the U.S. and gains on the sale or exchange of stock or securities issued by U.S. corporations. ${ }^{16}$ If, within the 15 -year period beginning five years before the expatriation and ending ten years after the expatriation, the expatriate exchanged property that had produced U.S. source income for property that produced foreign source income in a transaction that would otherwise have been entitled to nonrecognition treatment, the nonrecognition treatment would have been ignored and any gain would have been recognized..$^{17}$ If the disposition had occurred in the five years preceding expatriation, then the gain was to be recognized at the time of the loss of citizenship. ${ }^{18}$ If the disposition occurred in the ten years following expatriation, the gain was recognized and taxed in the year of disposition. ${ }^{19}$ The income and asset level for being subjected to the expatriation rules were similar to those of the new rules (see below). The former rules only applied if there was a tax avoidance motive for the expatriation. ${ }^{20}$ There was a rebuttable presumption that expatriation was tax-motivated. There is no such tax avoidance motive for the new rules to apply.

The Heroes Act labels the deemed disposition as "mark to market." In effect, the accrued (unrealized) gains and losses are deemed realized and recognized. The normal provisions of the Internal Revenue Code (Code), such as the netting of gains and losses, will apply to the deemed sales. An exception is that the "wash sales" provisions, which generally deny the recognition of losses if the same asset is sold and purchased within a 30-day period before or after the sale,

\footnotetext{
${ }^{16}$ IRC $\S 877(d)(1)$.

${ }^{17}$ IRC $\S 877(d)(2)$.

${ }^{18}$ IRC $\S 877(d)(2)(D)$.

${ }^{19}$ IRC $\S 877(\mathrm{~d})(2)(\mathrm{A})$ and Notice 97-19.

${ }^{20}$ IRC §877(f).
} 
will not apply. ${ }^{21}$ This makes sense as the deemed sale and immediate repurchase is required by the new law.

The U.S. rules for expatriates are far more generous than the Canadian rules. A major difference is that only a net gain that exceeds $\$ 600,000$ is taxed. ${ }^{22}$ The figure of $\$ 600,000$ will be adjusted for inflation in years after $2008 .^{23}$ This threshold pertains to each taxpayer; thus, for a married couple filing jointly the figure would be $\$ 1.2$ million (if both expatriate). It would appear that the basis of the asset, after the deemed sale, would be the deemed repurchase price without regard to the $\$ 600,000$ threshold. ${ }^{24}$ This step-up in basis only applies where the asset has been subject to the deemed disposition rules.

If instead of a net gain, after the netting process, a net capital loss is incurred, then the ability to use that loss is still limited by the normal loss deduction rules. For individuals, net capital losses can only be used against future capital gains, except for a maximum of $\$ 3,000$ (per year) that can be deducted from all other income. ${ }^{25}$

\section{Canada}

The Canadian law also has a deemed sale and repurchase requirement for certain assets when a taxpayer gives up Canadian residency. ${ }^{26}$ The Canadian rules are harsher than the U.S. rules, in that all Canadians who expatriate are subject to this rule. In other words, there is no income level threshold for the taxpayer nor a de minimus amount of deemed gain before any tax is applied. However, as a reporting matter, a taxpayer only needs to make a list of his assets in his final return if the amount of all assets owned at the time of departure is greater than Cdn $\$ 25,000 .{ }^{27}$ Furthermore, any personal-use property that has a value of less than Cdn $\$ 10,000$ need not be listed. The Cdn $\$ 10,000$ limit relates to each item of personal property. ${ }^{28}$

\section{Basis of Assets}

\section{United States}

A special rule the new law adds is that the basis of an asset (which is deemed to be sold) that was held by the taxpayer when that person became a U.S. resident is stepped up to the fair market value at the time that taxpayer became a U.S. resident. This rule means that any gain that accrued on the asset prior to the taxpayer becoming a U.S. resident would not be taxed under the "mark to market" rules. This provision is just a step-up in basis rather than a deemed disposition and repurchase of the asset at fair market value, as the law states that the asset "shall be treated as having a basis of not less than the fair market value ... on such date." 29 This step-up in basis is a departure from the usual rules for the U.S. Generally, the basis of an asset is the cost, even if held at the time the taxpayer became a U.S. resident, thus bringing in any

\footnotetext{
${ }^{21}$ IRC $\S 877 \mathrm{~A}(\mathrm{a})(2)(\mathrm{B})$ and $\S 1097$.

22 IRC $\S 877 A(a)(3)(A)$.

${ }^{23}$ IRC $\$ 877 A(a)(3)(B$.$) . For 2009, the amount is \$ 626,000$. Rev. Proc 2008-66 IRB 2008-45.

24 IRC $\$ 877 A(a)(2)$.

${ }^{25}$ IRC $\$ 121(\mathrm{~b})(1)$. This is limited to $\$ 1,500$ for taxpayers filing Married Filing Separately.

${ }^{26}$ Income Tax Act (ITA) §128.1(4)(b). This paper only deals with the Canadian federal law, and not any provincial law.

27 ITA §128.1(9).

${ }^{28}$ Canada Revenue Agency-Publication T4056 Rev. 08.

${ }^{29}$ IRC $\S 877 A(h)(2)$. Declines in value are ignored.
} 
gain accrued prior to being a U.S. resident under U.S. taxation. This special stepped-up basis rule is similar to the existing law in Canada.

\section{Canada}

The normal Canadian rule is that the basis of assets held at the time of immigration is their fair market value at that time. Canadian law deems there to be a sale and repurchase of the assets immediately before the taxpayer becomes resident in Canada. ${ }^{30}$ Thus, any appreciation in the value of such assets before a taxpayer becomes resident in Canada is not taxed in Canada. If the asset declined in value prior to immigration, the deemed sale/repurchase reduces basis which will reduce any future recognized loss or increase any future recognized gain.

\section{Expatriates}

\section{United States}

The U.S. rules apply only to relatively wealthy taxpayers. "Covered expatriates" include U.S. citizens who give up their citizenship and long-term residents who lose their residency status. These persons also have to meet one of three main tests. The tests are the same as in the superseded law: the "average tax liability" test, the "net worth" test, and the "noncertification" test. The "average tax liability" test applies to taxpayers who have had an average annual tax liability of $\$ 139,000$ (in 2008) (11 $^{31}$ in the five years ending in the year prior to expatriation; the "net worth" test applies to taxpayers who have \$2 million or more in net assets at the date of expatriation; the "noncertification" test is where the taxpayer has not certified (under penalties of perjury) that he has complied with all his federal U.S. tax requirements for the preceding five years or fails to provide evidence of such compliance as the Secretary may require. ${ }^{32}$ The "average tax liability test" and the "net worth test" do not apply if (1) the taxpayer was a dual citizen of the U.S. and a foreign country at birth, ${ }^{33}$ continues to be a citizen of that foreign country and is taxed by that country as a resident, and (2) had been a resident of the U.S. for not more that ten tax years in the 15 tax years ending with the tax year in which expatriation occurs. Those two tests ("average tax liability" and "net worth") also do not apply in the case of a taxpayer giving up his U.S. citizenship before the age of $181 / 2$, again not having been a resident of the U.S. for more than ten tax years in the 15 tax years ending with the tax year in which expatriation occurs.

\section{Canada}

All taxpayers who give up Canadian residency for tax purposes are regarded as expatriating and are subject to the deemed disposition rules. Unlike the U.S. rules, Canada does not have a dollar threshold amount for income nor for value of assets. As discussed above, it is a matter of fact whether a taxpayer has given up Canadian residency for tax purposes. Unlike the former U.S. rules, there is no tax avoidance presumption for the Canadian departure tax rules to apply.

\footnotetext{
30 ITA $\$ 128.1$ provides that the basis of assets of a new Canadian resident is their fair market value.

31 This will be increased by inflation annually. For 2009, the amount is \$145,000. Rev. Proc 2008-66 IRB 2008-45.

32 IRC $\S 877 A(f)$ referring to $\S 877(\mathrm{a})(2)$. Hereafter, the IRS will be used instead of the Secretary.

${ }^{33}$ A person can become a dual citizen at birth in a number of ways, depending on the laws of the countries involved. A common way is that a child is born in the U.S. (thus is a U.S. citizen) to foreign-citizen parents. The laws of that foreign country make a child of its citizens also a citizen of that country. Thus the child will have dual citizenships (U.S. and the foreign country) from birth.
} 
As mentioned above, there is no longer any tax avoidance motive on behalf of the expatriate for the new U.S. rules to be applied.

\section{Excluded Property}

\section{United States}

The new U.S. rules have exemptions to the "mark to market" provisions. There are three categories of exempt property: deferred compensation items, specified tax-deferred accounts, and interests in nongrantor trusts. ${ }^{34}$

Deferred compensation items include: ${ }^{35}$

1. employee pension plans (including stock bonus, pension, and profit-sharing plans), ${ }^{36}$ pension annuities, ${ }^{37}$ government pension plans, simplified employee pension plans, ${ }^{38}$ or simplified retirement accounts; ${ }^{39}$

2. foreign pension plans or similar retirement arrangements;

3. deferred compensation; and

4. property that the taxpayer is entitled to receive due to performance of services and not previously brought into income..$^{40}$

The treatment of these deferred compensation items differs depending on whether that item can be classified as an "eligible deferred compensation item" or not. For the deferred compensation to be "eligible," the person paying amounts under that deferred compensation plan must be a U.S. person or elect to be treated as a U.S. person (under any requirements of the IRS), and the expatriate notifies the payor of his status (as a covered expatriate). ${ }^{41}$ The expatriate also has to make an irrevocable waiver of any treaty rights with respect to that item. ${ }^{42}$ The rule for "eligible deferred compensation items" is that the payor must withhold 30 percent tax from the payment. ${ }^{43}$ Since there is this withholding tax on the payments from these "eligible" compensation accounts, there is no deemed sale of the assets held in them.

If the deferred compensation plan is not regarded as "eligible," then the taxpayer is deemed to have received an amount equal to the present value of the accrued benefit (of the deferred plan) on the day before expatriation. ${ }^{44}$ This could, of course, add substantial amounts to the taxpayer's ordinary income for that year. As the benefit is only deemed to be paid on the day before expatriation, any "additional tax" (usually 10 percent if the taxpayer is under 591/2 years old) that is normally payable due to early distribution is not applicable. ${ }^{45}$

\footnotetext{
${ }^{34}$ IRC $\S 877 A(c)(1),(2)$, and (3).

${ }^{35}$ IRC $\S 877(\mathrm{~A})(\mathrm{d})(4)$.

${ }^{36}$ IRC §401(a).

37 IRC $\$ 403(a)$ and (b).

38 IRC $\$ 408(k)$.

39 IRC $\$ 408(p)$

${ }^{40}$ IRC §83. Usually such property would not have been included in income if there was a substantial risk of forfeiture, until that risk was removed.

${ }^{41}$ IRC $\S 877 \mathrm{~A}(\mathrm{~d})(3)(\mathrm{A})$.

42 IRC $\S 877 A(d)(3)(B)$.

${ }^{43}$ IRC $\S 877 A(d)(1)(A)$.

${ }^{44} \mathrm{IRC} \S 877 \mathrm{~A}(\mathrm{~d})(2)(\mathrm{A})(\mathrm{i})$. If the property was subject to IRC $\S 83$, the risk of forfeiture is deemed not to apply and so the right to receive the property is deemed to occur on the day before expatriation. IRC $\S 877 A(d)((2)(A)(i i)$.

${ }^{45}$ IRC $\S 877 \mathrm{~A}(\mathrm{~d})(2)(\mathrm{B})$.
} 
Special rules apply to "specified tax-deferred accounts." Specified tax-deferred accounts include individual retirement accounts, ${ }^{46}$ qualified tuition plans, ${ }^{47}$ Coverdell education savings plans, ${ }^{48}$ health savings plans, ${ }^{49}$ and Archer Medical Savings Accounts. ${ }^{50,51}$ Expatriating taxpayers holding these plans are treated as having received a distribution of the entire plan on the day before expatriation. ${ }^{52}$ As in the case of the deferred compensation amounts, any penalty tax resulting from the deemed early distribution is not applicable. ${ }^{53}$ Furthermore, when amounts are actually distributed from these deferred accounts, appropriate adjustment would be made for the prior deemed distribution. ${ }^{54}$ The new law does not specify what these adjustments would be.

The third category of excluded property is nongrantor trusts. For the rules to apply, the expatriating taxpayer must have been a beneficiary of the trust on the day before expatriation. ${ }^{55}$ In these cases, the "mark to market" rule will not apply. Instead, there is a 30 percent withholding tax on the taxable portion of any distribution to the expatriate. ${ }^{56}$ The "taxable portion" of a distribution is the amount of that distribution which would have been includable in the expatriate's income if the expatriate had been subject to tax as a citizen or resident of the U.S. ${ }^{57}$ In addition, if the property distributed has an accrued gain (that is, the fair market value is greater than its adjusted basis), the property is deemed to have been sold at its fair market value by the trust, to the beneficiary. The gain on the deemed sale is recognized by the trust. ${ }^{58}$

A grantor trust is not excluded property. Thus, the assets are deemed sold and repurchased by the trust under the "mark to market" rules on the day before expatriation of the owner. ${ }^{59} \mathrm{~A}$ grantor trust is a trust in which the grantor (generally the person who sets up the trust) retains some substantial rights in the trust. ${ }^{60}$

\section{Canada}

Canada generally does not have the concept of a grantor trust. Trusts are the owners of the property in the trust. Thus, a taxpayer giving up Canadian residency who is the beneficiary of a trust does not have to apply the deemed disposition rules to the assets of the trust. However, if the trust is regarded as being set up as an avoidance technique prior to expatriation, then the assets could be subject to the deemed disposition rules. ${ }^{61}$

The Canadian deemed disposition rules, for taxpayers giving up Canadian residency, do not apply to certain property situated in Canada (called "taxable Canadian property") and deferred

\footnotetext{
${ }^{46}$ As defined in IRC §408(a) or (b), but excluding simplified employee pensions (IRC §408(k)) or simplified retirement accounts $(\mathrm{IRC} \S 408(\mathrm{p}))$ - as these are included in the definition of deferred compensation items, see above.

47 As defined in IRC $\$ 529$.

48 As defined in IRC $\$ 530$.

49 As defined in IRC $\$ 223$.

50 As defined in IRC $\$ 220$.

51 IRC $\S 877 A(e)(2)$.

${ }^{52}$ IRC $\S 877 \mathrm{~A}(\mathrm{e})(1)(\mathrm{A})$.

${ }^{53}$ IRC $\S 877 A(e)(1)(B)$.

${ }^{54}$ IRC $\S 877 A(e)(1)(C)$.

55 IRC $\S 877 A(f)(5)$.

${ }^{56}$ IRC $\$ 877 A(f)(1)(A)$.

57 IRC $\$ 877 A(f)(2)$.

${ }^{58}$ IRC $\$ 877 A(f)(1)(B)$.

59 Joint Committee on Taxation Report JCX-44-08.

60 IRC \$673-677 and \$679.

61 ITA §104(4)(a.3).
} 
plans such as registered retirement savings plans, registered retirement income funds, registered education savings plans, deferred compensation amounts, foreign retirement arrangements and pensions. ${ }^{62}$ Registered retirement savings plans are equivalent to IRAs and registered education savings plans are equivalent to U.S. deferred-tuition plans (e.g., §529 plans).

Taxable Canadian property that is excluded includes:

1. Canadian real estate, Canadian resource property, timber resource property; and

2. property (including inventory) used in a business carried on in Canada through a permanent establishment in Canada. ${ }^{63}$

The reason for excluding taxable Canadian property is that the gains from these properties can be taxed in Canada to nonresidents. ${ }^{64}$ However, the taxpayer can elect to treat taxable Canadian property as being disposed. ${ }^{65}$ This is useful if the taxpayer has other losses that can shelter the gains on the taxable Canadian property (and also obtain an increase in the adjusted cost basis). Alternatively, if the taxable Canadian property has accrued losses, an election would realize the losses that could be used against the gains from other dispositions and deemed dispositions. However, the use of the losses can be restricted only to gains otherwise deemed realized. ${ }^{66}$ If the former resident disposes of the excluded taxable Canadian property at a loss (when a nonresident), he can elect effectively to "carry back" that loss against the gains resulting from the deemed disposition when he left Canada. ${ }^{67}$

Certain property owned by short-term Canadian residents can also be excluded from the deemed disposition rules. A short-term resident is a taxpayer who has been resident in Canada for not more than 60 months in the 120-month period that ends at the time residency is given up. The additional exempt property is property that was owned by the taxpayer at the time he last became resident in Canada, or that was acquired by the taxpayer by inheritance or bequest after the taxpayer last became resident in Canada, and still held at the time of expatriation. ${ }^{68}$ Thus, a short-term resident who has kept property throughout his stay in Canada is not taxed on any accrued gains on that property accrued while that taxpayer was resident in Canada. As stated above, the U.S. "mark to market" rules apply only to long-term residents (those who have been resident in the U.S. for at least eight years out of the 15 years prior to expatriation) and thus there is no need for specific rules for short-term residents. ${ }^{69}$

\section{Election to Defer Payment}

Since the deemed sale and repurchase do not result in any inward cash flow, the expatriating taxpayer may not have the funds to pay the extra tax. Both Canadian residents, who are subject

\footnotetext{
62 ITA §128.1(4)(b)(iii) and $§ 128.1(10)(a)$.

63 ITA $\$ 128.1(4)(\mathrm{b})$ (i) and (ii).

64 ITA \$116. The normal rule is that nonresidents of Canada are taxed on any gains made on "taxable Canadian property." Thus, there is no need to apply the deemed disposition rules to this type of property, since the expatriating resident would be taxed on any such gains in any event.

65 ITA $\$ 128.1(4)(d)$.

66 ITA $\$ 128.1(4)(d)($ iii).

67 ITA $\$ 128.1(8)$.

${ }^{68}$ ITA $\$ 128.1(4)(d)(i v)$. The Canadian rules only define a "short-term" resident. There is no definition of a "long-term" resident, as there is in the U.S. rules.

${ }^{69}$ It is possible that a noncitizen who becomes a naturalized U.S. citizen then decides to expatriate, even though he had been resident in the U.S. for less than eight years. Presumably the "mark to market" rules would still apply to such a person.
} 
to the departure tax, and expatriating U.S. citizens or residents, subject to the "mark to market" rules, face this problem.

\section{United States}

The new U.S. legislation permits an expatriating taxpayer to elect to postpone payment of the additional tax resulting from the application of the "mark to market" rules. ${ }^{70}$ Payment is generally delayed until the due date of filing the return for the year in which the property is sold. ${ }^{71}$ However, if the expatriate dies prior to selling the property, then the additional tax is due by the due date of filing the final return of the deceased person.

For the election to defer payment to apply, adequate security must be posted. ${ }^{72}$ The security can be a bond (at a value that covers the tax and any interest due on the unpaid tax) which is furnished to, and accepted by, the IRS under the provisions of Code $\$ 6325 . .^{73}$ Other security, such as a letter of credit that meets the requirements of the Secretary, may also be furnished. ${ }^{74}$

The election does have a cost. Interest is charged on the postponed tax at the rate for underpaid tax for individuals. ${ }^{75}$ This interest rate runs from the due date of filing the return for the year of expatriation to the time the tax is actually paid. The interest rate is the same as that charged on any other underpayment of tax.

If the security posted for the deferral fails to meet the requisite tests (and the failure is not rectified within the time limit set out by the IRS), then again the additional tax has to be paid by the due date of the return for the year in which the failure occurs. ${ }^{76}$ The election is made on a property-by-property basis and, once made, is irrevocable. ${ }^{77}$ Furthermore, the taxpayer must agree to waive, irrevocably, any rights under a treaty with the U.S. that may preclude assessment or collection of the postponed tax. ${ }^{78}$

If several properties are held at the time of expatriation and only one is sold at a later date, then the amount of additional tax relating to the sold property has to be determined. This is done by taking the same ratio of the additional tax due to the deemed sale in the year of expatriation as the ratio of deemed gain that the now-sold asset had to the gains of all the assets subject to "mark to market" rules. ${ }^{79}$

For example, an expatriating taxpayer has two properties, A and B, subject to the "mark to market" rules. Property A has a gain of $\$ 10,000,000$ and Property $B$ has a gain of $\$ 15,000,000$ and the additional tax is $\$ 3,150,000 .{ }^{80}$ The ratio is 40 percent $(\$ 10 \mathrm{M} / \$ 25 \mathrm{M})$ for Property $A$ and 60 percent $(\$ 15 \mathrm{M} / \$ 25 \mathrm{M})$ for Property $\mathrm{B}$. If the election to defer payment is made and Property A is sold five years later, the additional tax in that year would be $\$ 1,260,000(\$ 3,150,000 \times 40$ percent).

\footnotetext{
70 IRC §877A(b).

${ }^{71} \operatorname{IRC} \S 877 \mathrm{~A}(\mathrm{~b})(1)$.

${ }^{72}$ IRC $\$ 877 A(b)(4)$.

${ }^{73}$ IRC $\S 877 \mathrm{~A}(\mathrm{~b})(4)(\mathrm{B})(\mathrm{i})$.

${ }^{74}$ IRC $\S 877 A(b)(4)(B)(i i)$.

${ }^{75}$ IRC $\S 877 A(b)(7)$.

${ }^{76}$ IRC $\S 877 \mathrm{~A}(\mathrm{~b})(3)$.

${ }^{77}$ IRC $\S 877 A(b)(6)$.

${ }^{78}$ IRC $\S 877 A(b)(5)$.

${ }^{79}$ IRC $\S 877 A(b)(2)$.

$80 \$ 25 \mathrm{M}$ gain $\times 15$ percent tax rate equals $\$ 3.75 \mathrm{M}$. Less the $\$ 600,000$ threshold gives additional tax of $\$ 3.15 \mathrm{M}$.
} 
Deferring payment of the tax until the asset is sold would seem to be a likely strategy for many expatriating taxpayers. However, the cost is having to supply adequate security and that interest accrues on the postponed tax.

\section{Canada}

Similarly, Canadian law permits expatriating taxpayers to defer payment of the departure tax, if they post adequate security. ${ }^{81}$ Security is only required if the amount of federal tax owing from the deemed disposition of property is more than $\mathrm{Cdn} \$ 14,500$. The security must be greater than the amount of deferred tax. The taxpayer may also be required to provide security to cover any applicable provincial or territorial tax payable. Unlike the new U.S. rules, interest is not normally payable on the deferred payment.

\section{GIFTS AND BEQUESTS TO A U.S. CITIZEN OR RESIDENT}

The U.S. has a federal estate and gift tax regime, which can be quite onerous. ${ }^{82}$ The U.S. estate and gift tax does not apply to non-U.S. persons (other than those holding U.S.-situs assets). Therefore it would be possible for a taxpayer to avoid gift or estate taxes by making the gift (or holding property until death) after he has become an expatriate. To counteract this possibility, the Heroes Act adds new provisions for U.S. citizens or residents receiving gifts from an expatriate or bequests from a deceased expatriate. ${ }^{83}$ The tax on the gift or bequest is the highest estate tax rate (or the highest gift tax rate, if higher) times the value of the gift or bequest. ${ }^{84}$ Since collecting tax from expatriates is difficult, it is the recipient of the gift or bequest who is liable for the tax. ${ }^{85}$ The legislation refers to a "covered" gift or bequest. A "covered" gift or bequest is any property acquired, directly or indirectly, by gift from an expatriate, or by reason of the death of an individual who was an expatriate immediately before dying. ${ }^{86}$

If the expatriate or estate of a deceased expatriate timely files a gift tax return or an estate tax return, any property included on those returns is not regarded as "covered" gifts and bequests. ${ }^{87}$ Also excluded are transfers to charities or spouses that would otherwise be exempt from gift or estate taxes under the normal rules. ${ }^{88}$ Furthermore, the annual per donor per donee gift tax exception will apply to "covered" gifts and bequests. ${ }^{89}$ For example, if the value of the gift is $\$ 20,000$, tax would be charged on $\$ 8,000$ (the amount that exceeds the exemption amount of $\$ 12,000$ ). Some foreign countries have their own estate (or gift) taxes. To alleviate any double taxation, the new law provides that if the expatriate or estate of a deceased expatriate pays any foreign tax on the gift or bequest that foreign tax will reduce the tax imposed by the new law on the donee or beneficiary. ${ }^{90}$

Instead of making a direct gift (or leaving a bequest) to a U.S. citizen or resident, the expatriate could transfer the property to a trust. The new law has provisions that address this kind of transfer. If the trust is a U.S. domestic trust, then the same rules would apply to the trust as

\footnotetext{
81 ITA §220(4.5).

${ }^{82}$ Canada does not have a federal estate or a federal gift tax, so there are no similar concerns.

${ }^{83}$ Heroes Act $\S 301(\mathrm{~b})$ adds $\$ 2801$ to the Internal Revenue Code.

84 IRC $\$ 2801(a)$.

85 IRC $\$ 2801(b)$.

86 IRC $2801(e)(1)$.

87 IRC $\$ 2801(\mathrm{e})(2)$.

${ }^{88}$ IRC §2801(e)(3) referring to IRC §2055 (estate charitable transfer), §2056 (estate spousal transfer), §2533 (gift charitable transfer), and $\S 2523$ (gift spousal transfer).

89 IRC §2801(c) and §2503(b).

90 IRC $\$ 2801(d)$.
} 
they would to an individual. ${ }^{91}$ In this case, it is the trust that would be responsible for paying the tax rather than the beneficiaries. ${ }^{92}$ If the trust is a foreign trust, then the new law cannot apply to the trust, but will apply to property that is distributed to a U.S. citizen or resident. The distributed property, whether from income or corpus, that is attributable to the "covered" gift or bequest is treated as if it were a "covered" gift or bequest. ${ }^{93}$ The U.S. citizen or resident would be the person liable for the tax as before. How much of the distribution would be attributable to the "covered" gift or bequest is not specified by the new law. Presumably, regulations will be issued to indicate how to calculate the amount attributable. ${ }^{94}$ If the distribution from the foreign trust is included in the U.S. citizen's or resident's gross income, then a deduction for the tax paid, due to these new rules, can be deducted from the gross income. ${ }^{95}$ A foreign trust can also elect to be treated as a domestic trust for the purposes of these rules. This election is revocable with permission of the IRS. ${ }^{96}$ In this case, the foreign trust would pay the tax on any "covered" transfer to it.

\section{CONCLUSION}

Both Canadian and U.S. legislators are concerned about taxpayers obtaining a tax advantage by removing themselves from the respective country's tax system. In Canada it is a relatively simple method of becoming nonresident for tax purposes. In the U.S. it is rather more complex for citizens who wish to give up formally their U.S. citizenship (though it is much easier to give up long-term residency status). The approach used by the two countries is different. Whereas the Canadian solution of deemed disposition can apply to all persons giving up their tax residency, the U.S. solution of "mark to market" (although also a deemed sale) applies only to taxpayers with high income in the five years before expatriation, and even then only if the gain on the assets "marked to market" is substantial (over $\$ 626,000$ in 2009). If a taxpayer is leaving the country permanently to a new life in another country, it is quite possible that he would choose to realize his gains by selling his assets before expatriating and using those funds to buy assets in the new country. This is more likely to be the case for expatriating long-term residents whose connections with the U.S. tend to be less strong than expatriating U.S. citizens.

If assets are left behind, and because of the cost and possible hardship of having to pay tax on accrued but not realized gains, both the Canadian and U.S. laws permit the taxpayer to defer payment until the assets are sold, if security is posted. The U.S. rules include interest on the deferred tax liability, whereas the Canadian rules do not. It is likely that many expatriating taxpayers would chose to defer paying the tax until after they have sold the assets.

Both countries have exemptions from the general rule that assets are deemed disposed for assets relating to deferred compensation such as pensions and retirement funds, with Canada also exempting certain Canadian-situs real estate and business assets. The U.S. does not exempt U.S-situs real estate or business assets.

The U.S. is also concerned with expatriates circumventing the federal estate and gift tax by gifting or bequeathing assets after expatriating. This may be more of a problem for expatriating

\footnotetext{
91 IRC $\$ 2801(\mathrm{e})(4)(\mathrm{A})(\mathrm{i})$.

92 IRC $\$ 2801(\mathrm{e})(4)(\mathrm{A})(\mathrm{ii})$.

93 IRC $\$ 2801(\mathrm{e})(4)(\mathrm{B})(\mathrm{i})$.

${ }_{94}$ Methods to do this could include: (1) the distribution is first considered attributable to the gift or bequest, or (2) a proportional amount of the distribution is so attributable (e.g., if 24 percent of the assets of the trust came from the "covered" gift, then 24 percent of the distribution could be regarded as attributable).

${ }^{95}$ IRC §2801(e)(4)(B)(ii) and §164.

${ }^{96}$ IRC §2801(e)(4)(B)(iii).
} 
U.S. citizens who are likely to have family (and other potential beneficiaries) still living in the U.S. (or are U.S. citizens) than for former long-term residents. The Canadian authorities do not have such concerns as there are no federal estate or gift taxes in Canada.

The Heroes Act has made expatriation potentially very expensive. Wealthy U.S. citizens and long-term residents need to consider the new rules carefully before deciding to avoid future U.S. tax by expatriating. However, if taxpayers have assets that have little or no accrued appreciation (or most of their assets in cash), the cost of expatriating could be minimal or none. This could well be the case in the current economic climate. Furthermore, once the U.S. taxpayer has expatriated, he can return for visits to the U.S. and not be concerned with the 30-day rule as he would have been under the former law. The new law is likely to have both winners and losers compared to the former law, so taxpayers and their advisors need to consider all the circumstances to ascertain whether expatriation is beneficial.

Further research could ascertain whether the new rules have encouraged the number of U.S. citizens or long-term residents not to expatriate. Research can also be conducted to quantify the benefit, if any, that the new provisions have given to the Treasury. 